\title{
29. NEOGENE AND QUATERNARY PELAGIC SEDIMENTS AND DEPOSITIONAL HISTORY OF THE EASTERN EQUATORIAL PACIFIC OCEAN (LEG 138) ${ }^{1}$
}

\author{
Alan E.S. Kemp ${ }^{2}$
}

\begin{abstract}
Analysis of the variation in Neogene and Quaternary sediment types in the eastern Equatorial Pacific Ocean reveals distinctive spatial and temporal patterns. Miocene sediments are nannofossil oozes with increased diatom contents in equatorial sites. All the major Miocene carbonate-silica variations within near equatorial sites and in the early and middle Miocene age sediments of Site 844 , result from the episodic and widely correlatable sedimentation of laminated diatom mat deposits. In sites farther from the equator, the only major middle-late Miocene carbonate/silica variation is a period of carbonate dissolution that developed over several hundred thousand years and had a maximum intensity at 8.92 to $8.71 \mathrm{Ma}$. The complex and varied causes and expressions of carbonate/silica (and, hence, seismic impedance contrast) variation during the early late Miocene suggest that great care will be required in the use of seismic reflectors as agents for correlating oceanographic events. Diatom mat deposits and their bioturbated remnants are found in some sites north of the equator, and in some to the south, suggesting a link with the Equatorial Current systems. Major changes occurred during the Pliocene, with (1) no preservation of diatom mat deposits after 4.37 Ma; (2) a major carbonate dissolution episode between 3.88 and $3.18 \mathrm{Ma}$; and (3) the inclusion of foraminifers as an important sediment component in middle Pliocene through Quaternary sediments. In contrast to the diatom mat deposits, a major Pliocene-Pleistocene interval of elevated diatom contents and diatom-rich interbeds is best developed to the south at Site 846 and fades to the west and north, suggesting a strong link to the Peru Current/South Equatorial Current (PC-SEC) system.
\end{abstract}

\section{INTRODUCTION}

The range of surface- and deep-water processes involved and the steep gradients in temperature, productivity, and sediment flux in the eastern equatorial Pacific Ocean have combined to produce diverse pelagic sedimentary facies. Previous studies of changes in the accumulation patterns of these sediments highlighted several significant spatial and temporal changes during Neogene and Quaternary time (e.g., van Andel et al., 1975; Leinen, 1979; Mayer, Theyer, Thomas., et al., 1985). The principal objective of Leg 138 was to generate a series of continuous sediment sections (Fig. 1), both along and across the equator that would facilitate a new definition and understanding of these spatial and temporal variations.

The purpose of this study is to complement the profusion of multiparameter data sets produced from Leg 138 cores (either "remotely sensed" or taken from homogenized samples) by synthesizing the observational sedimentology performed during shipboard core description and in subsequent shore-based study. These observational data are critical for distinguishing the relative influence of surfaceand deep-water processes in producing the sedimentary record (for example, the gamma-ray attenuation porosity evaluator [GRAPE] signal cannot distinguish between diatom-rich interbeds and radiolarian-rich interbeds).

There is increasing use, within the field of paleoceanography, of multi-parameter data sets, either taken from discrete samples (stable isotopes, quantitative micropaleontology, nutrient/proxy analysis) or by continuously measured parameters (GRAPE; magnetic susceptibility, and so forth). This has led to a reduction in the role of observational sedimentology (visual core description) to such an extent that important features of the cores in the past have been overlooked. Recently, however, observational sedimentology, based on detailed visual core description and photography enhanced by electron microscopy has played a key role in identifying extensive laminated

'Pisias, N.G., Mayer, L.A., Janecek, T.R. Palmer-Julson, A., and van Andel, T.H. (Eds.), 1995. Proc. ODP. Sci. Results, 138: College Station, TX (Ocean Drilling Program).

Department of Oceanography, University of Southampton, Southampton SO9 5NH, United Kingdom.

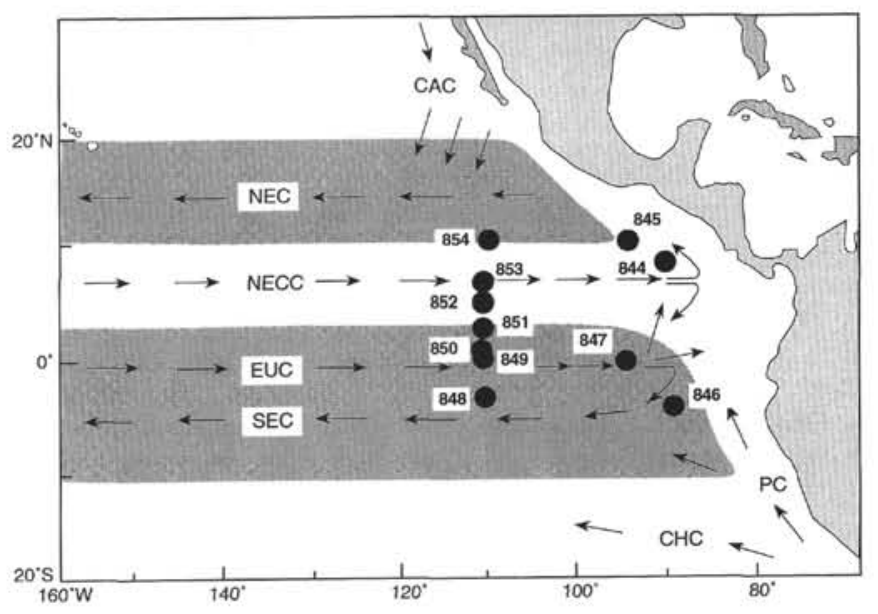

Figure 1. Location map for Leg 138 sites showing position with respect to major current systems. Arrows indicate surface and subsurface currents. CAC $=$ California Current; NEC $=$ North Equatorial Current; NECC $=$ North Equatorial Countercurrent; EUC $=$ Equatorial Undercurrent; $\mathrm{SEC}=$ South Equatorial Current; $\mathrm{PC}=$ Peru Current; $\mathrm{CHC}=$ Chile Current. Shaded areas indicate the general latitudinal extent of the SEC and NEC.

diatom mat deposits within the eastern equatorial Pacific, both in Leg 138 cores and in DSDP Leg 85 cores (Kemp and Baldauf, 1993).

Apart from the distinctive laminated diatom mat deposits described in detail elsewhere (Kemp and Baldauf, 1993; Pearce et al.; Kemp et al.; King et al., this volume) several other distinctive sediment types and facies were identifiable in many of the Leg 138 cores. Sediment characterization is based primarily on variations in color, bedding characteristics, fabrics, distinctive minor lithology components (e.g. sediment preserved only in burrow fills), and composition deduced from smear-slide analysis. Almost all smear-slide analysis during Leg 138 was conducted by three operators: M. Leinen, M. Levitan, and A. Kemp. The combination of a small number of experienced observers and intercallibration led to a high level of consistency in results. These results are the basis for the Leg 138 site 


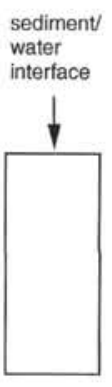

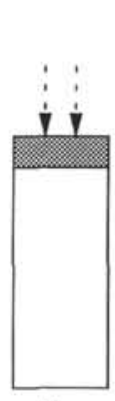

rapid

deposition

of diatom

mats

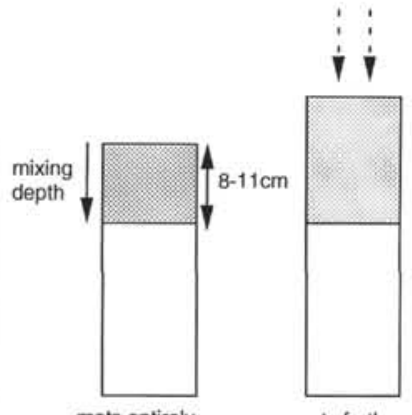

mats entirely fragmented and diluted and pervasively mixed after bioturbation mixed after continued deposition

Effect of deep burrowers

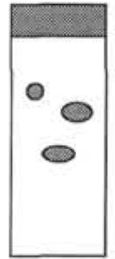

Imposition of deep burrows below mixed layer
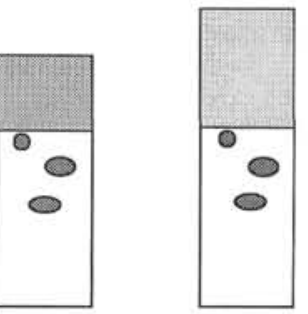

Deep burrows preserve T.longissima mats from complete homogenization
Figure 2. Deep burrows preserve near-end-member sediment from complete homogenization in the surface mixed layer. The top series shows the mixing and "diluting" effects of bioturbation on a deposit of contrasting composition to that of the enclosing sediment. The lower series shows the effect of deep burrowers that rapidly remove some near-surface sediment below the mixed layer, resulting in preservation of material nearer the original surface-layer sediment composition.

summary logs produced in Figures 5 through 7 . In addition, a number of minor sediment features, such as burrow fills, and some subtle variations in sediment color and composition were used to distinguish important trends in deposition that are discussed below.

\section{TIME SCALES AND CORRELATION}

The time scale of Berggren et al. (1985) is used, together with a few modifications to the age of datums resulting from refined magnetostratigraphic/biostratigraphic correlation. These are detailed in the explanatory notes of Mayer, Pisias, Janecek, et al. (1992). The tuned time scale given in Shackleton et al. (this volume) and used by other authors is now known to be incorrect as a result of "tuning" through intervals of diatom mat deposits (N. Shackleton, pers. comm., 1993). Discussion about the timing of changes in sedimentation is based on magnetic polarity time scales and nannofossil and diatom datums given in Mayer, Pisias, Janecek, et al., (1992). Note that many nannofossil datums are located to within a few centimeters in the cores. The ages quoted to one or two decimal places below are mostly nannofossil datums. The sedimentation rates given below are bulk sedimentation rates, based again on Berggren et al.'s (1985) time scale and listed in full in the individual site chapters of Mayer, Pisias, Janecek, et al. (1992). To permit intercomparison and correlation with other studies, I have included reference to specific biostratigraphic and paleomagnetic reference datums.

\section{SIGNIFICANCE OF MINOR LITHOLOGIES OCCURRING IN BURROW FILLS}

Burrow fills encountered in many Leg 138 cores are not only distinguished by different coloration, but often also by differences in composition, from the enclosing sediment. Such burrow fills preserved in deep-sea cores represent the last imposed burrows beneath the surface mixed layer (8-11 cm deep, Gage and Tyler, 1990) that are emplaced by deep burrowers (Berger et al., 1979; Ekdale et al., 1984; Kemp, this volume). The mechanism of formation of these structures provides a means of preserving surficial sediments, by rapid transit through the surface mixed layer, where complete homogenization occurred (Fig. 2). Thus, burrow fills contain near-end-member sediment compositions, more representative of any changing flux or bottom-water conditions that led to their formation. They are particularly useful in preserving a record of rapidly sedimented material, such as diatom mat deposits (Fig. 2; Pl. 3). Two distinct examples of burrows that contain near-monospecific assemblages of Thalassiothrix longissima (the mat-forming diatom) occur in the record. The most common comprises darker olive gray ( $5 \mathrm{Y}$ hue), T. longissima-rich burrow fills within paler nannofossil ooze (Pl. 3, Fig. 2). Considerable variation is seen in the intensity of this type. In intervals interbedded with laminated diatom ooze, abundant dark burrows commonly contain $T$. longissima mat fragments (Pl. 3, Fig. 2). Dark, diatom-rich burrows also are common during mat-forming episodes within sites that do not contain laminated diatom ooze (e.g., $4.4 \mathrm{Ma}$ at Site 851 ). There is a continuous spectrum from this type to burrows that contain less pure, diatom-nannofossil ooze within nannofossil ooze sequences (such as the early Miocene sediments at Site 844). The second, less common, form of diatom-rich burrow fill comprises pale, near-monospecific $T$. longissima burrows within brownish, low sedimentation-rate sequences that vary from foraminifer ooze to oxide-rich clay (Pl. 3, Fig. $3)$. This burrow type is confined to earliest late Miocene age sequences at Sites 845 and 852 . These remnants of original layers provide important and unique information about the depositional history.

\section{PALE/DARK INTERBEDS: CARBONATE SILICA CYCLICITY}

Many of the sequences encountered during Leg 138 drilling are characterized by decimeter- to meter-scale alternations between pale (calcareous-rich) and darker (siliceous) lithologies. Even in sequences having almost no color variation discernable with the naked eye, the color scanner often detected a color variation that could be correlated with a variation in the GRAPE signal (Mix et al., 1992, and this volume).

In lower sedimentation-rate sequences (about $15 \mathrm{~m} / \mathrm{m} . \mathrm{y}$. or less), there is commonly an alternation between paler brown carbonatebearing sediment and darker brown, carbonate-poor, clay and/or oxide-rich interbeds (Pl. 1). In some carbonate dominated sequences having low sedimentation rates, oxide-rich interbeds occur without any increase in the relative abundance of siliceous microfossils (e.g., Pleistocene through late Pliocene age section at Site $852 ; \sim 12 \mathrm{~m} / \mathrm{m} . \mathrm{y}$; Pl. 1, Fig. 1). This style of interbedding probably results from dissolution of carbonate and may be regarded as a "dissolution facies."

In sediments having deposition rates between 15 and $30 \mathrm{~m} / \mathrm{m}$.y., variations in the relative abundance of carbonate and silica may result from two distinct variations in sediment composition: (1) an alternation between paler carbonate-rich and darker, more radiolarian-rich interbeds, and (2) an alternation between paler carbonate-rich and darker, more diatom-rich interbeds. At any given site or interval, either radiolarian-rich or diatom-rich interbeds appear dominant, with 

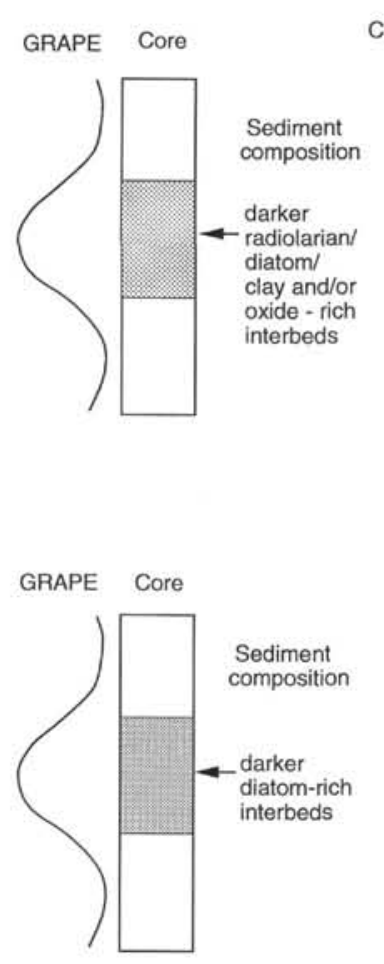

Carbonate dissolution cyclicity

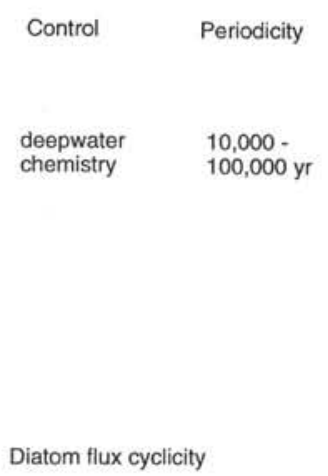

$$
\text { Control Periodicities }
$$

$\begin{array}{lc}\begin{array}{lc}\text { surfacewater } \\ \text { processes }\end{array} & 10,000- \\ & 100,000 \mathrm{yr} \\ & \text { AND }\end{array}$

ca. $500-1000 \mathrm{yr}$ for mat deposits
Figure 3. The contrasting types and origins of high frequency variation in carbonate content in equatorial Pacific Ocean cores produce similar GRAPE records. Decimeter- to meter-scale interbedding is caused by dissolution (top), resulting in beds lower in carbonate with some or all of increased radiolarians, diatoms, clay, and/or Fe and Mn oxides. This style of variation is caused by variations in the dissolution of carbonate related to deep-water chemistry and has periodicities of 10,000 to $100,000 \mathrm{yr}$, within the Milankovitch band. The lower figure shows variation resulting from increased diatom flux, which may be at similar periodicities or, in the case of diatom mat deposits, one or two orders of magnitude faster.

diatom-rich interbeds dominating in near-equatorial sites (PI. 2). An informative exception to this occurs in Site 848, where pale/dark alternations are detectably the result of both diatom and radiolarian variations. In Core 138-848C-3H, the background (dominant) lithology is a diatom/foraminifer nannofossil ooze. Superimposed on this are two distinct, darker sediments: one is diatom nannofossil ooze (up to $35 \%$ diatoms) with a distinct olive $(5 \mathrm{Y})$ hue; the other is a radiolarian nannofossil ooze (up to $20 \%$ radiolarians, $5 \%$ clay) with a characteristic greenish $(5 \mathrm{G})$ hue. In the same time interval (1.89-1.45 Ma) at several sites, carbonate-silica cyclicity is dominated by the occurrence of (pervasively bioturbated) diatom-rich interbeds, which are indicated in the lithologic columns (below).

In intervals having high sedimentation rates of 30 to $50 \mathrm{~m} / \mathrm{m}$.y., such as the Pliocene through Pleistocene at Site 846, diatom-rich interbeds are the dominant agent of carbonate-silica cyclicity.

Within the highest sedimentation-rate intervals of diatom mat deposition (bulk sedimentation rates of between 100 to more than 150 $\mathrm{m} / \mathrm{m} . \mathrm{y}$.), decimeter- to meter-scale carbonate-silica variability results from an alternation between laminated diatom ooze (mat deposits) and diatom nannofossil ooze. The length scale of this variation is similar to those described above (Fig. 3; Pl. 2, Fig. 3), although the time scale of formation is at least an order of magnitude less (Kemp and Baldauf, 1993, this volume). This mat-deposit cyclicity poses pitfalls for the production of orbitally tuned time scales based on the

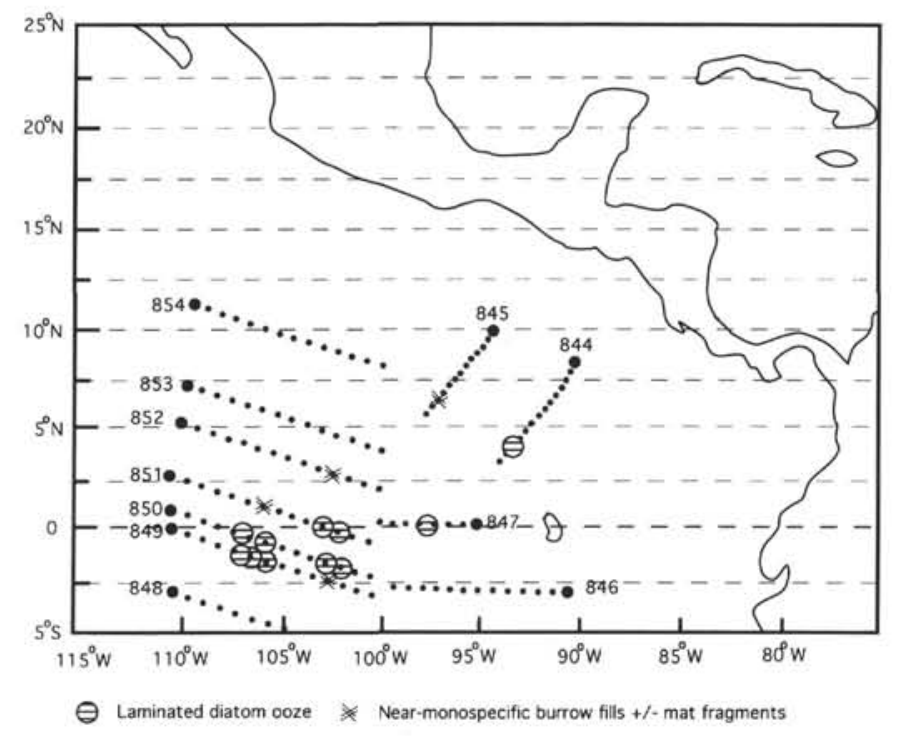

Figure 4. Plate-motion backtracked diagram showing location through time (one dot per 1 m.y.) of laminated diatom mat deposits and traces of diatom mat deposition (burrow fills and mat fragments).

GRAPE and can lead to errors in the generation of a tuned time scale (Shackleton, this volume). A thorough "ground-truthing" of the GRAPE record is a prerequisite for understanding the origins of carbonate-silica cyclicity in the equatorial Pacific Ocean on all time scales.

\section{SUMMARY OF FACIES VARIATION AND DEPOSITIONAL HISTORY}

The sites drilled during Leg 138 can be conveniently represented in three separate transects: the two sites drilled northeast of the Galapagos Islands $(844,845)$; the $110^{\circ} \mathrm{W}$ north-south equatorial transect (Fig. 1) (848-854), and an east-west equatorial transect showing sites between $110^{\circ} \mathrm{W}$ and the Galapagos Islands $(849,846,847)$. Sites 848 through 854 are separated from 846 and 847 by the East Pacific Rise and thus have diverged progressively during spreading (Fig. 4). Lithofacies summary diagrams for these transects are shown in Figures 5 through 7 .

\section{Eastern Sites $(844,845)$}

\section{Site 844}

Lower and middle Miocene sediments at Site 844 are predominantly nannofossil oozes deposited at rates of between 25 and 40 $\mathrm{m} / \mathrm{m}$.y. Early to middle Miocene deposition of foraminifer nannofossil ooze was succeeded in middle Miocene (at $150 \mathrm{mbsf}$ ) by diatom nannofossil ooze, which persisted into early late Miocene time. The foraminifer nannofossil ooze is punctuated by dark, diatom-rich burrow fills that increase in frequency and diatom-abundance in middle Miocene time from $200 \mathrm{mbsf}$ and become abundant in the diatom nannofossil ooze from 150 mbsf. The only major interruptions in carbonate deposition are intervals of laminated to bioturbated diatom mat deposits (Kemp and Baldauf, 1993, this volume). The youngest and thickest of these intervals had ceased $\sim 1 \mathrm{~m}$ below B. Catinaster coalitus $(11.1 \mathrm{Ma})$. An abrupt transition (coinciding with a reduction in sedimentation rate to about $7 \mathrm{~m} / \mathrm{m}$.y.) is seen through an earliest late Miocene age, meter-scale alternation of variably diatomor nannofossil-rich sediments to almost $10 \mathrm{~m}$, dominated by carbonate-free, clayey, radiolarian ooze that spans the time interval top of Chron C5 to top of Chron C4A (8.92-7.9 Ma). During the remainder of late Miocene and early Pliocene time, an alternating sequence of 


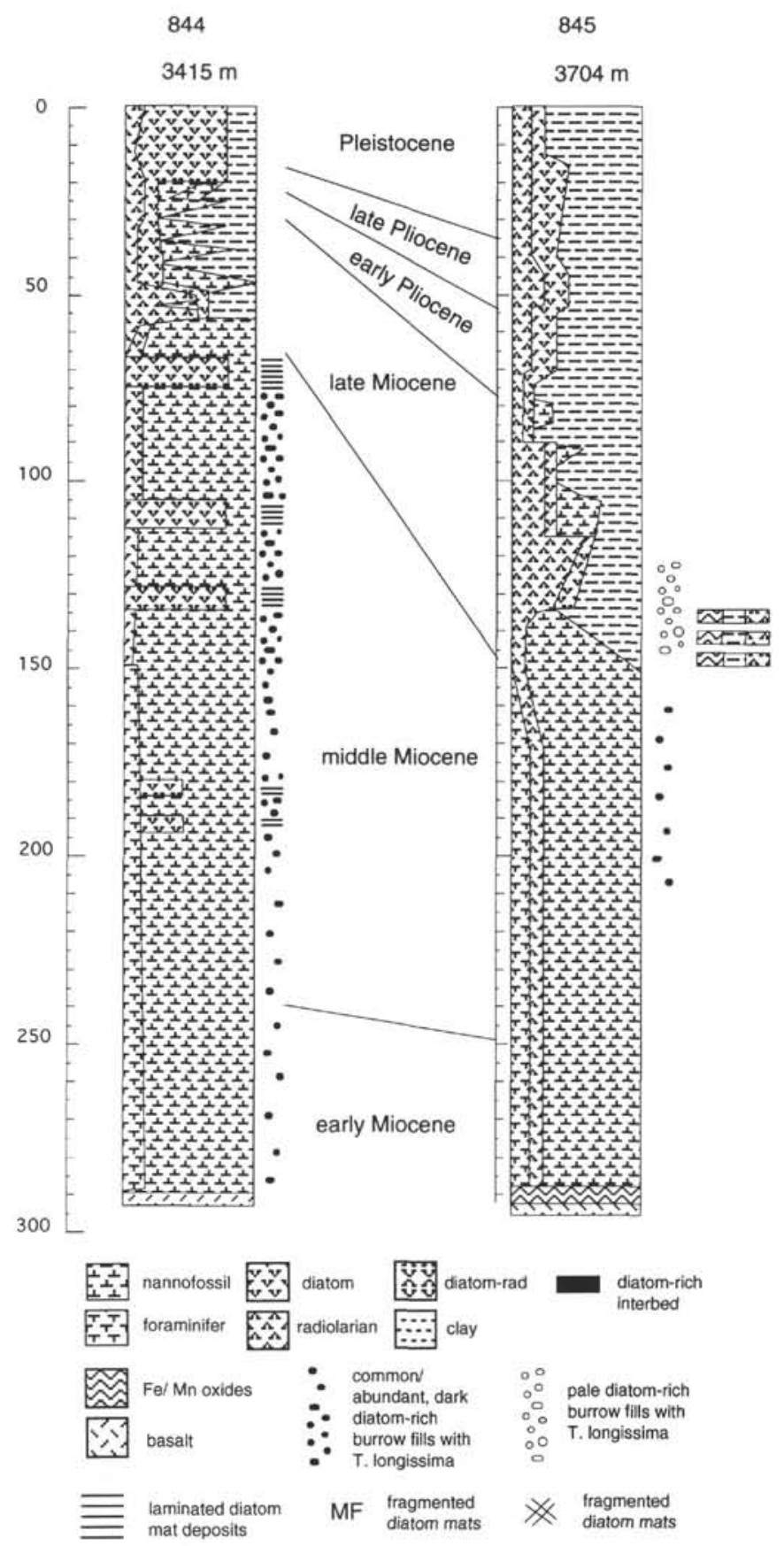

Figure 5. Lithostratigraphic summaries of Sites 844 and 845 , northeast of the Galapagos Islands.

calcareous and siliceous oozes and clays was deposited at rates of about $5 \mathrm{~m} / \mathrm{m}$.y. Pleistocene sediments are mainly carbonate-free, radiolarian clayey diatom ooze deposited at rates of 10 to $15 \mathrm{~m} / \mathrm{m}$.y.

At Site $845,2.5 \mathrm{~m}$ of spectacular, red, basal metalliferous sediment is overlain by a sequence similar to that of Site 844 . This early to middle Miocene age foraminifer nannofossil ooze, having a variable radiolarian content, is characterized by a meter-scale alternation from the dominant lithology of foraminifer nannofossil ooze to thinner $(10-30 \mathrm{~cm})$, slightly darker beds of radiolarian nannofossil ooze (Pl. 1, Fig. 5). Sedimentation rates during this interval varied from 20 to 30 $\mathrm{m} / \mathrm{m}$.y., except for the early Miocene record, where diatom age datums suggest sedimentation rates of about $50 \mathrm{~m} / \mathrm{m}$.y. (although no sedimentological evidence supports this). Darker, diatom-rich burrow fills occur in sediments between 210 and $160 \mathrm{mbsf}$. The foraminifer content declined rapidly (together with sedimentation rates) during latest middle Miocene time. During earliest late Miocene time, a transitional sequence ( $150-135 \mathrm{mbsf}, \sim 10 \mathrm{~m} / \mathrm{m} . \mathrm{y}$.) punctuated by $\mathrm{Fe}$ - and Mn-oxide-rich beds (Pl. 2, Fig. 2) recorded a more gradual change (than that of Site 844) from carbonate-dominated deposition to siliceous deposition, with the sequential upward loss of foraminifers, coccoliths and finally, discoasters by 157 mbsf. Thus, at Site 845 , carbonate deposition had ceased about $2 \mathrm{~m}$ below the top of Chron C5 (8.9 Ma), penecontemporaneous with, or slightly earlier than, Site 844. There follows a 20 -m sequence of almost featureless, mainly grayish green, carbonate-free, clayey radiolarian ooze/radiolarian clay, which was deposited at higher sedimentation rates of about 20 $\mathrm{m} / \mathrm{m} . \mathrm{y}$. Common, pale burrow fills having near-monospecific concentrations of the diatom $T$. longissima (PI. 3, Fig. 3) occur between 144 mbsf (T. C. miopelagicus, $9.94 \mathrm{Ma}$ ) to $122 \mathrm{mbsf}(\mathrm{C} 4-\mathrm{n} 1(\mathrm{t})-\mathrm{C} 4 \mathrm{~A}-$ $\mathrm{n} 1(\mathrm{o}) / 7.9-8.21 \mathrm{Ma})$. Carbonate deposition resumed about $2 \mathrm{~m}$ above the top of Chron C4A (7.90 Ma), coincident with a short normal polarity feature near the base of Chron C4 (see "Paleomagnetism" section in "Site 845 " chapter (Mayer, Pisias, Janecek, et al., 1992). The rest of the late Miocene record comprises mainly radiolarian clays, with some paler, more calcareous horizons. Pliocene and Pleistocene sediments comprise green radiolarian diatom clay deposited at sedimentation rates of $\sim 12 \mathrm{~m} / \mathrm{m}$.y., increasing to $20 \mathrm{~m} / \mathrm{m}$.y. in Pleistocene and up to $30 \mathrm{~m} / \mathrm{m}$.y. in late Pleistocene time. This Pliocene-Pleistocene section also is characterized by higher concentrations of organic matter and common-to-abundant Zoophycos burrows (Kemp, this volume).

\section{Comparison of Sites 844 and 845}

The overall facies distribution patterns of Sites 844 and 845 are similar. A carbonate-dominated early and middle Miocene section is succeeded by a carbonate-free interval in the early late Miocene and a more variable late Miocene to Pliocene section. The middle Miocene intervals of laminated diatom ooze that are confined to Site 844 represent the only major variations in carbonate/silica abundance prior to the earliest late Miocene carbonate decline at both sites. At Site 845, the late Miocene transition from carbonate to siliceous sedimentation was more gradual and encompassed the interval 10.59 to $9 \mathrm{Ma}$. Between 9 and $7.9 \mathrm{Ma}$, radiolarian and clay-rich sediments were deposited at both sites, but at higher rates $(\sim 20 \mathrm{~m} / \mathrm{m}$.y. $)$ at Site 845 . Between 7.9 and $2.57 \mathrm{Ma}$ at Site 844 and 7.9 to $5.35 \mathrm{Ma}$ at Site 845 , alternating deposition of carbonate-free and carbonate-bearing siliceous clays occurred. At Site 844, the upper Pliocene and Pleistocene sediments are diatom ooze, while at Site 845 , lower Pliocene through Pleistocene sedimentation comprises virtually carbonate-free siliceous ooze or siliceous clay.

\section{North-South Equatorial Transect}

\section{Site 848}

Site 848 represents the southernmost site of the equatorial transect. The basal sediments comprise $5 \mathrm{~m}$ of probable latest middle Miocene age foraminifer nannofossil ooze that is succeeded by $\sim 5.5$ $\mathrm{m}$ of early late Miocene age nannofossil ooze that contains oxide-rich interbeds. This interval of oxide-rich interbeds is capped by a $\sim 50-\mathrm{cm}$ clay-rich horizon that occurs in the interval between the top of Chron C5 to Chron C4A-n3 (8.92-8.71 Ma). This clay-rich horizon is succeeded by radiolarian nannofossil ooze, which persists up to early Pliocene, when the proportion of diatoms increases. A zone of siliceous microfossil- and clay-rich interbeds is present between 34 and $28 \mathrm{mbsf}$ (ca. 4.1-2.47 Ma), and within this interval, foraminifer abundances increase to become a major sediment component. The upper Pliocene through Pleistocene sediments are foraminifer nannofossil oozes. A few diatom-rich interbeds occur between 1.89 and $1.45 \mathrm{Ma}$ (see discussion of interbeds, above). 


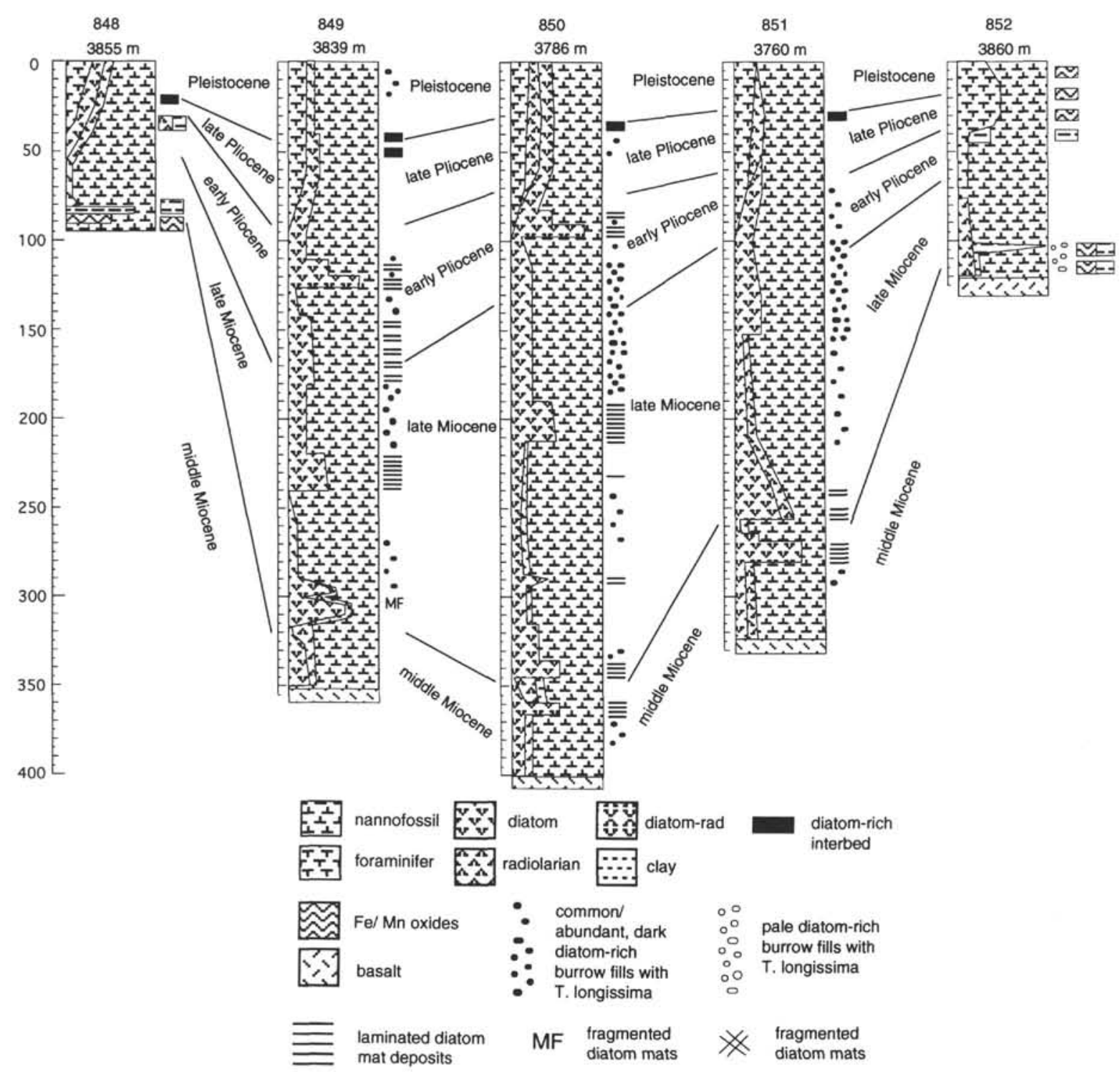

Figure 6. Lithostratigraphic summaries of the north-south transect at $110^{\circ} \mathrm{W}$ : Sites 848 through 852 .

\section{Near-equator Sites: 849,850 , and 851}

In the near-equator sites (849-851), sediments deposited between 12 and 4 Ma were almost exclusively diatom nannofossil ooze (Fig. 6). Major variations in nannofossils and diatoms within this interval are dominated by the episodic occurrence of laminated to bioturbated diatom mat deposits. The oldest laminated diatom ooze is a latest middle Miocene age interval present at Sites 850 and 851 . B. Catinaster coalitus $(11.1 \mathrm{Ma})$ is located near the top of this interval at Site 851. The latest middle Miocene to earliest late Miocene interval is characterized at Sites 849,850 , and 851 by a minimum abundance of diatoms and by a relative increase in radiolarians, which become the dominant siliceous microfossil. Increases in radiolarians are most pronounced at Sites 849 and 850 , where increased clay also is recorded. These bioturbated diatom radiolarian nannofossil oozes are succeeded in the earliest late Miocene, immediately above T. Coccolithus miopelagicus $(9.94 \mathrm{Ma} ; 4 \mathrm{~m}$ above at Site 851 and $3 \mathrm{~m}$ above at Site 850 ), by a further interval of laminated diatom ooze. No obvious lithological expression of the latest middle Miocene laminated diatom ooze interval is seen at Site 849, although GRAPE data do record a more silica-rich interval (Mayer, Pisias, Janecek, et al., 1992; Bloomer et al., this volume). The earliest late
Miocene laminated interval (Sites 850,851 ) does correspond to a diatom-rich section at Site 849 , in which diatom mat fragments are observed in the richest diatom ooze bed (located $11 \mathrm{~m}$ above $\mathrm{T}$. Coccolithus miopelagicus).

The earliest Miocene interval of laminated diatom ooze (LDO) at Site 851 is not vertically extensive (see Pearce et al., this volume) and had ceased long before the datum T. Discoaster hamatus $(8.67 \mathrm{Ma})$, as had sedimentation of diatom mat fragments at Site 849. This datum was not identified at Site 850, but LDO deposition is considerably more vertically extensive here than at Site 851 . Following this interval, the proportion of diatoms in all sites decreased and reached a minimum at Site 849, immediately prior to the onset of the next major episode of deposition of LDO (6.42-6.02 Ma; B. Amaurolithus primus-B. Amaurolithus amplificus). LDO also is present at this interval at Site 850. No LDO is present within this interval at Site 851, although there is a contemporaneous abrupt increase in the diatom content of sediment, and abundant burrow fills contain near-monospecific assemblages of $T$. longissima. Sediments having abundant diatoms were continuously deposited after this period of LDO deposition at all sites, and a further period of intermittent LDO deposition occurred at Site 849, while sediments deposited at Sites 850 and 851 contain abundant ( $T$. longissima) diatom-rich burrow fills. 


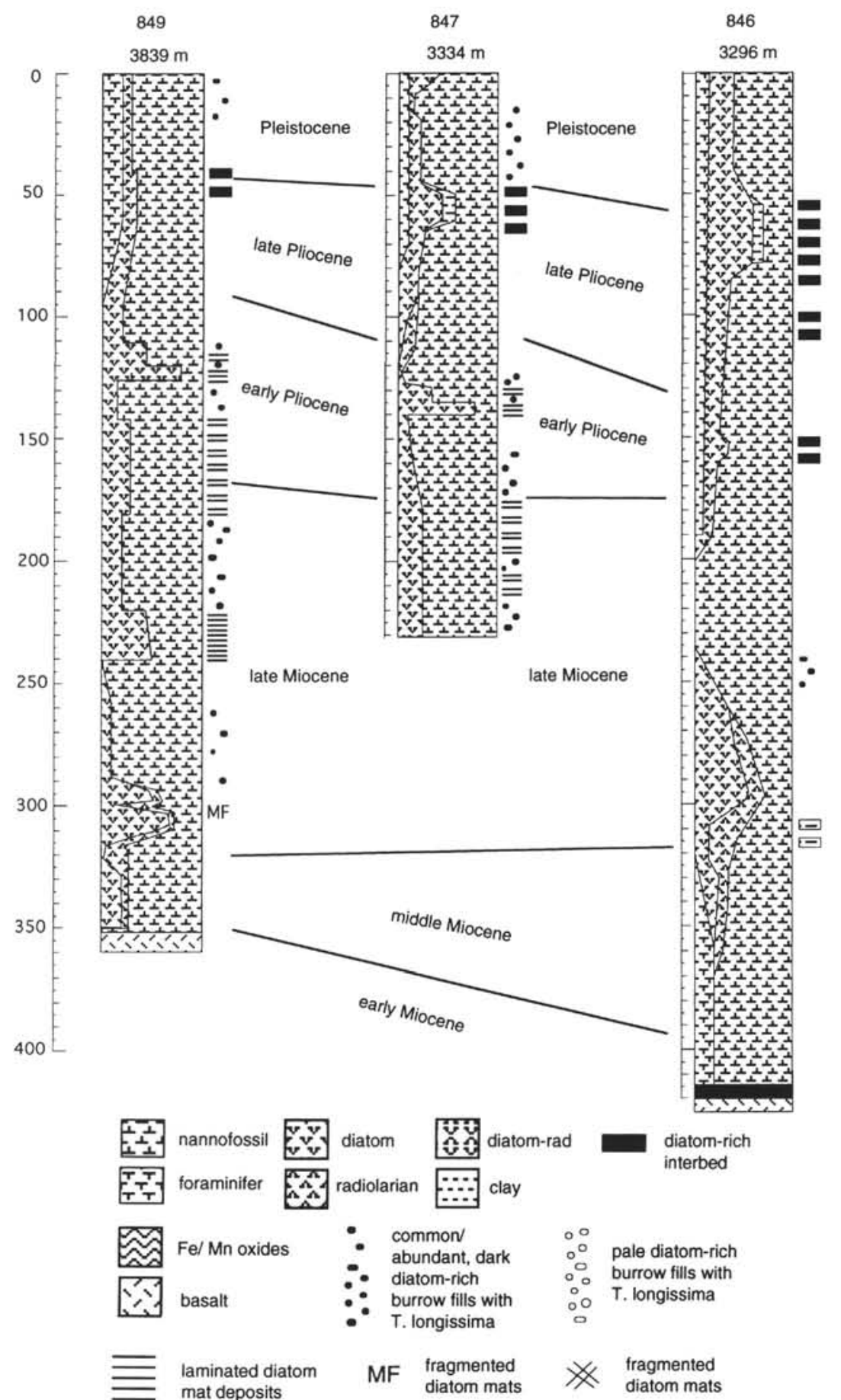

Figure 7. Lithostratigraphic summaries of an east-west transect through Sites 849,847 , and 846 , between $110^{\circ} \mathrm{W}$ and the Galapagos Islands.

Variation in sedimentation rates in the middle Miocene through Pliocene sediments in Sites 849 through 851 is closely related to the presence or absence of laminated diatom mat deposits (although the lower frequency of good datums in the older Miocene sections makes this relationship more tenuous for the period prior to $8 \mathrm{Ma}$ ). Thus, at Site 849 , prior to the first occurrence of laminated diatom ooze, sedimentation rates were between 30 and $50 \mathrm{~m} / \mathrm{m}$.y., other than for an interval of low sedimentation rates of $12 \mathrm{~m} / \mathrm{m} . \mathrm{y}$. between 10 and 8 $\mathrm{Ma}$. However, during the interval of regular occurrence of laminated diatom ooze (6.42-4.43 Ma), sedimentation rates ranged from 60 to $110 \mathrm{~m} / \mathrm{m}$.y. At Site 850 , sedimentation rates varied between 38 and 47 $\mathrm{m} / \mathrm{m}$.y. during the interval from 11 to $8.8 \mathrm{Ma}$ (within which two thin LDO deposits occur), then decreased to values between 27 and 44 $\mathrm{m} / \mathrm{m}$.y. and between 8.8 and $6.75 \mathrm{Ma}$, but increased to values greater than $120 \mathrm{~m} / \mathrm{m}$.y. between 6.75 and $6 \mathrm{Ma}$, during the time of the main interval of LDO deposition. At Site 850, no clear link is seen between the latest middle and earliest late Miocene diatom mat deposits and increased sedimentation rates, with Miocene through early Pliocene 
rates ranging between 35 and $60 \mathrm{~m} / \mathrm{m}$.y. Late Pliocene through Pleistocene sedimentation rates for Sites 849 through 851 vary between 20 and $30 \mathrm{~m} / \mathrm{m} . \mathrm{y}$.

After ca. $4 \mathrm{Ma}$ in the equatorial transect (Fig. 6), the only correlation in bulk lithology observed between all sites is the increase in foraminifers as a sediment component, so that upper Pliocene and Pleistocene sediments are foraminifer nannofossil oozes. This increase appears more gradational in the sites having higher sedimentation rates near the equator (Sites 849-851). The precise degree of synchroneity of this gradational change cannot be assessed accurately from the available smear slide data alone. Distinctive diatom-rich interbeds are common in the record between 1.89 and $1.45 \mathrm{Ma}$ (Pl. 2, Fig. 2), and are most common at Site 849 , while decreasing in frequency and diatom abundance northward through Sites 850 and 851 .

\section{Site 852}

Sedimentation at Site 852 commenced during the latest middle Miocene, with radiolarian nannofossil oozes containing oxide-rich intervals that were deposited at rates of between 5 and $10 \mathrm{~m} / \mathrm{m}$.y. At 108 mbsf, a distinctive $~ 2-\mathrm{m}$ interval of reduced carbonate, in which sedimentation rates decrease to $3 \mathrm{~m} / \mathrm{m}$.y., contains a $25-\mathrm{cm}$ bed of carbonate-free radiolarian clay with oxides (Pl. 4). This important horizon occurs between the top of Chron C5 and Chron C4A-n3 (8.92-8.71 Ma) and correlates with a similar horizon at Site 848 (see above). There followed a cessation of the oxide-rich beds and deposition of pale brown radiolarian nannofossil ooze, with foraminifers at elevated sedimentation rates of around $21 \mathrm{~m} / \mathrm{m}$.y. between 7.9 and 7.5 $\mathrm{Ma}$. Sedimentation rates decreased to $\sim 12 \mathrm{~m} / \mathrm{m}$.y. between 7.5 and 6.42 Ma. After this, a period of increased deposition rates (to about 20 $\mathrm{m} / \mathrm{m}$.y.) occurred together with a color change to light greenish gray, punctuated by darker gray radiolarian-rich interbeds. During the earliest Pliocene (between 4.67 and $3.83 \mathrm{Ma}$ ), sedimentation rates fell to rates of about $12 \mathrm{~m} / \mathrm{m}$.y., and the color of the background sediment reverts to pale brown within a transitional sequence of brown to dark brown, clay-rich interbeds in the Cochiti-Mammoth interval (3.88$3.18 \mathrm{Ma}$ ). Thereafter, the abundance of foraminifers rapidly increases so that upper Pliocene through Pleistocene sediments are foraminifer nannofossil oozes or nannofossil foraminifer ooze. This sequence contains regular interbeds of darker brown oxide-rich sediments. Interestingly, no trace is seen of any interval of more diatom-rich interbeds near the Pliocene/Pleistocene boundary, as at Sites 846 through 851 .

\section{Site 853}

Sedimentation at Site 853 commenced during the late Miocene between 9 and $8 \mathrm{Ma}$ with clayey nannofossil ooze. Upper Miocene sediments have variable clay content and include some intervals with purer nannofossil ooze (e.g., at 49-44.5 mbsf; between B. A. amplificus and B. A. primus: $6.42-6.02 \mathrm{Ma}$ ). During the early Pliocene, sedimentation rates decreased from late Miocene values of 12 to 15 $\mathrm{m} / \mathrm{m}$.y. to Pliocene through Pleistocene rates of 4 to $8 \mathrm{~m} / \mathrm{m}$.y. Sediments were more clay-rich (10\%-30\%), and foraminifers became an increasing sediment component, during the early Pliocene, with late Pliocene to Pleistocene abundances of $20 \%$ to $50 \%$.

\section{East-West Equatorial Transect: Sites 846 and 847}

The lithological columns for Sites 846 and 847 are shown in Figure 7, with Site 849 included for reference.

\section{Site 846}

The oldest deposits at Site 846 are poorly recovered lower Miocene metalliferous sediments overlying basalt. These are overlain by foraminifer nannofossil chalks, which pass up, in the middle Miocene interval, into foraminifer nannofossil ooze deposited at rates of 10 $\mathrm{m} / \mathrm{m}$.y. Toward late middle Miocene time, the proportion of foraminifers decreased and the abundance of radiolarians and diatoms increased, so that the sediments are radiolarian diatom nannofossil oozes, other than for a short interval that spanned the middle/late Miocene boundary to the early late Miocene, where radiolarians are the dominant siliceous microfossil (Sites 849-851). Interbeds of diatom radiolarian clay, which are sometimes carbonate-free, also occurred during this interval. From about $8.67 \mathrm{Ma}$ (T. Discoaster hamatus) to about $7.5 \mathrm{Ma}$ (T. Discoaster berggreni), the sediments are dominated by diatom ooze, which passes up into a characteristic alternation between dark diatom ooze beds and radiolarian diatom nannofossil ooze. Middle Miocene through late Miocene sedimentation rates are constant at values of about $15 \mathrm{~m} / \mathrm{m}$.y. but these increased at about $7 \mathrm{Ma}$ to rates of between 40 and $50 \mathrm{~m} / \mathrm{m}$.y. for the late Miocene through Pliocene age section. Radiolarians are rapidly lost as a significant sediment component around $10 \mathrm{~m}$ above T. Discoaster berggreni, and diatoms at about $10 \mathrm{~m}$ below B. Amaurolithos primus (6.42 Ma). Following this, the top upper Miocene sediments are nannofossil ooze with diatom abundances of less than $5 \%$. Diatom abundances increase immediately prior to the Miocene/Pliocene boundary (T. Discoaster quinqueramus, $4.98 \mathrm{Ma}$ ). Pliocene sediments are predominantly diatom nannofossil ooze with variable minor foraminifer content with interbeds of nannofossil diatom ooze. The end of the late Pliocene sequence (5-10 $\mathrm{m}$ above T. Discoaster surculus, $2.41 \mathrm{Ma}$, to T. Calcidiscus macintyrei, $1.45 \mathrm{Ma}$ ) is marked by a thick interval of olive gray to dark olive gray nannofossil diatom ooze and clayey diatom ooze, interbedded on a meter-scale with paler diatom nannofossil ooze. Diatom abundances decreased during the early Pleistocene, and the dominant sediment thereafter was a foraminifer diatom nannofossil ooze with darker, more diatom-rich interbeds deposited at rates of about 30 to $40 \mathrm{~m} / \mathrm{m} . \mathrm{y}$.

\section{Site 847}

Upper Miocene sediments at Site 847 comprise diatom nannofossil ooze with common diatom-rich interbeds (Pl. 2, Fig. 1) and sparse interbeds of laminated diatom ooze deposited at rates of 30 to 40 $\mathrm{m} / \mathrm{m}$.y. Diatom abundances decreased during the early Pliocene to reach a minimum prior to a thicker, prominent interval of LDO with sedimentation rates $(4.98-4.37 \mathrm{Ma})$ in excess of $80 \mathrm{~m} / \mathrm{m}$.y. More radiolarian-rich sediments were then deposited at rates of about 25 $\mathrm{m} / \mathrm{m}$.y. in an interval that spanned the early Pliocene/late Pliocene boundary (4.37-3.56 Ma). Thereafter, diatom nannofossil ooze and, following a late Pliocene increase in foraminifer content, foraminifer diatom nannofossil ooze was deposited at rates of about $30 \mathrm{~m} / \mathrm{m}$.y. Sedimentation rates increased to about $40 \mathrm{~m} / \mathrm{m}$.y. during deposition of an interval of more diatom-rich interbeds between 1.89 and 1.45 $\mathrm{Ma}$ (see discussion below).

\section{MIOCENE-PLIOCENE VARIATION IN CARBONATE AND SILICA: CARBONATE DISSOLUTION AT DEPTH VS. SURFACE SILICA PRODUCTIVITY AND FLUX}

An important and recurrent question in paleoceanography concerns the relative importance and interaction of surface- and deep-water processes. The record of these processes is most commonly preserved as a variation in the relative proportions of biogenic carbonate and silica in sediments. Small (decimeter to meter)-scale, high-frequency $(10,000 \mathrm{yr})$ variations in the relative abundance of carbonate and silica are discussed above and illustrated in Figure 3 and Plates 1 and 2. Major, longer time period changes in carbonate and silica in the equatorial Pacific Ocean have been the subject of extensive discussion, both in terms of perceived carbonate dissolution events and their implications for deep-water circulation (e.g., Mayer et al., 1985), and in relation to major shifts in the locus of silica cycling and deposition within the ocean basins (Leinen, 1979; Brewster, 1980). With the 


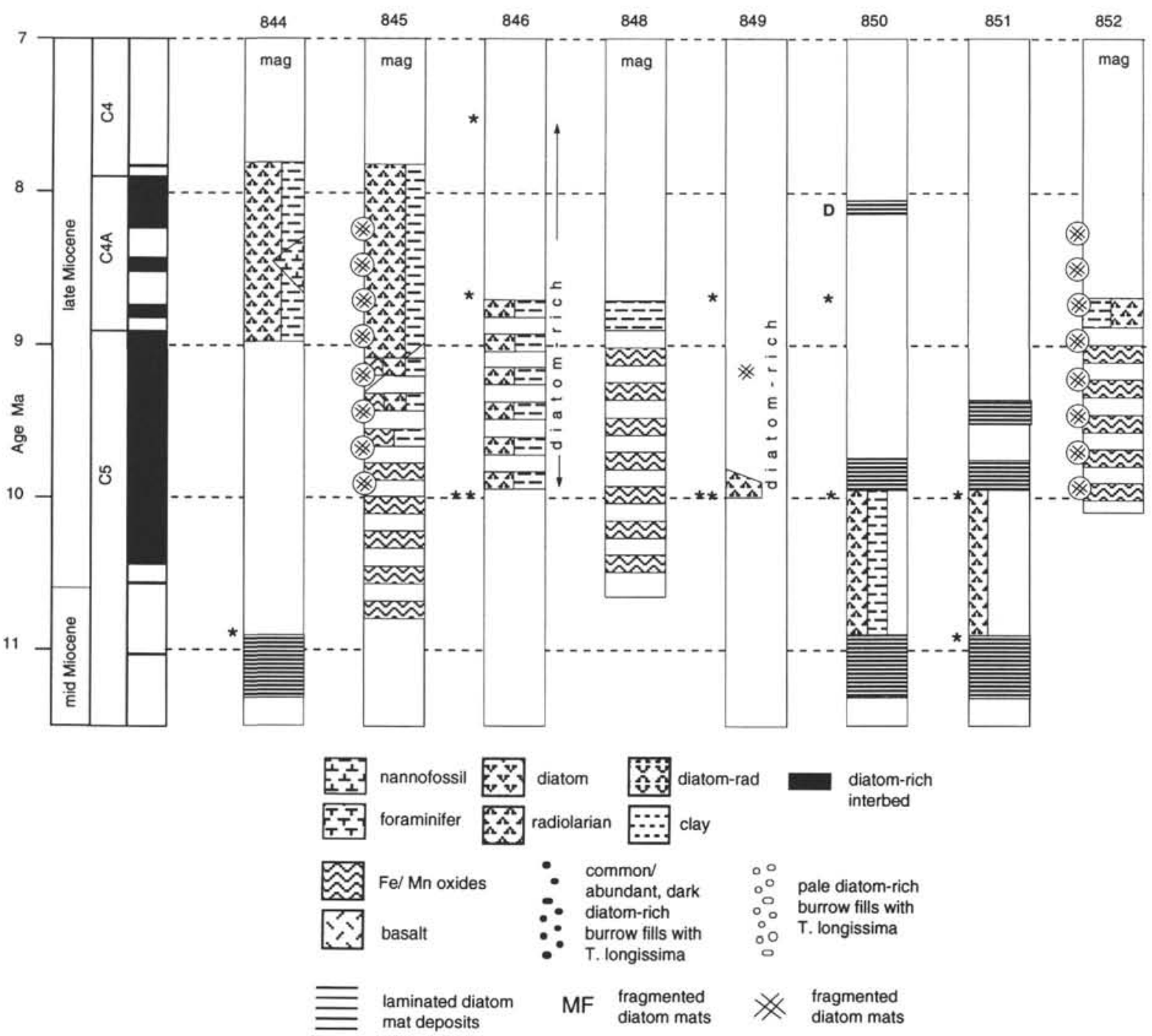

Figure 8. Summary of the major noncarbonate lithologies in the time interval from 11.5 to $7 \mathrm{Ma} ;{ }^{*}=$ nannofossil datums; $\mathrm{D}=$ diatom datum; $\mathrm{mag}=$ dating from paleomagnetic data.

excellent new data provided by Leg 138 drilling, it is now possible to review the origins of carbonate/silica variation in the eastern equatorial Pacific. The summary logs of Figures 5 through 7 show clearly that major variations in silica abundance are dominated by the occurrence of laminated diatom mat deposits. Indeed, prior to the middle Miocene/late Miocene boundary, all major carbonate/silica variations in Leg 138 sites were the result of deposition of LDO.

Some of the largest and most widespread variations in carbonate occurred during early late Miocene time (Fig. 8). Analysis of the interval from 11.5 to $7 \mathrm{Ma}$ shows that a complex interplay of both surface- and deep-water processes took place during this period. The end of one of the most widespread intervals of diatom mat deposition coincides with a nannofossil datum (B. Catinaster coalitus) at 11.1 Ma. Little evidence exists in carbonate records in the sites having continued episodic diatom mat deposition $(850,851)$ for significantly reduced carbonate immediately following this episode. However, diatoms ceased to be a major sediment component and were replaced by radiolarians at both Sites 851 and 850 (which also has an increased clay component) prior to the next major interval of LDO deposition, which commences shortly after $9.94 \mathrm{Ma}$. A radiolarian-rich section is present in Site 849 in this interval. A decline in carbonate at Site 845 is heralded by the deposition of interbeds rich in oxides and progressively also clay and radiolarians. Oxide-rich interbeds are present at Sites 848 and 852 in the interval 9.94 to $8.7 \mathrm{Ma}$, and clay and radiolarian rich interbeds span the period from 9.94 to $8.67 \mathrm{Ma}$ at Site 846 . The total loss of carbonate at Sites 844 and 845 coincides with thin, carbonate-free clay horizons and minimum sedimentation rates at both Sites 848 and 852 in the time interval from 8.92 to $8.71 \mathrm{Ma}$ (paleomagnetically dated). This interval marks the maximum intensity and extent of carbonate dissolution and corresponds to the "purple" reflector of Mayer et al. (1985), which has been related to an increase in the intensity of North Atlantic Deep Water production. Carbonate deposition resumed and sedimentation rates increased at both Sites 848 and 852 following this, and intermittent carbonate deposition resumed at Sites 844 and 845 shortly after 7.9 Ma. Throughout this period (9.9-8 Ma) at Sites 850 and 851 , relatively high sedimentation rates $(30-60 \mathrm{~m} / \mathrm{m} . \mathrm{y}$.) persisted and variations in carbonate are the result of intermittent diatom mat deposition. Although intact diatom mat deposits are not present in other sites in this interval, exotic burrows having near-monospecific concentrations of T. longissima at Sites 845 and 852 suggest periodic episodes of diatom mat deposition that were insufficient to overwhelm the benthos (Kemp and Baldauf, 1993; Kemp et al., this volume; Pearce et al., this volume).

After about 8.5 Ma, the only further Miocene through Pliocene major reduction in carbonate in the nonequatorial sites is a dissolution event within the Cochiti-Mammoth interval (3.88-3.18 Ma) (the "Green" reflector of Mayer et al., 1985). This is most pronounced at Site 852, where clay-rich horizons occur, and at Site 853 to the north, but is of smaller magnitude at Site 848 . This interval coincides with a 
return to near carbonate-free deposition at Site 844 . By contrast, in the equatorial sites $(847,849,850,851)$, late Miocene through Pliocene carbonate-silica variation is large, but entirely dominated by episodes of diatom mat flux up to $4.37 \mathrm{Ma}$, after which no diatom mat deposits were recognized in Leg 138 (or DSDP Leg 85) sites. Following the cessation of massive mat deposition, diatom-rich sediments (including some intervals rich in T. longissima) continued to be deposited in the equatorial sites, but these are present in thoroughly bioturbated interbeds (Pl. 2).

\section{THE PLIOCENE-PLEISTOCENE HIGH PRODUCTIVITY PERIOD}

A significant decrease in the carbonate content of the equatorial sites in the latest Pliocene to early Pleistocene interval results from an increase in the diatom content of the background sediment and from the presence of diatom-rich interbeds (Figs. 6 and 7). T. longissima is dominant within these sediments, but no diatom mats have been preserved. This interval is thickest at Site 846 , where diatom contents increased rapidly during the late Pliocene and reached a peak between 2.41 and $1.45 \mathrm{Ma}$. At Site 847, elevated diatom contents and diatomrich interbeds are present in the interval from 1.89 to $1.45 \mathrm{Ma}$. Increased silt and clay contents at these sites suggest increased wind strengths during this period (see Hovan, this volume). Farther west, this event is less pronounced, with the most significant increase in diatom content occurring, together with diatom-rich interbeds, at Site 849. Some diatom-rich interbeds are present at Site 848 , but the sedimentary expression of the event decreases in intensity to the north, and no trace exists at Site 852 (or 853). The timing of the onset of this high productivity period suggests a link with the onset of Northern Hemisphere glaciation (ca. 2.4 Ma; Shackleton et al., 1984).

\section{CONCLUSIONS}

The summary presented above shows that relatively few systematic, long-term changes in sediment composition occurred within the eastern equatorial Pacific. Lower and middle Miocene sediments are foraminifer or radiolarian nannofossil oozes, with significant diatom contents only in the near-equator sites. In the near-equator sites, intermittent deposition of laminated diatom mat deposits represents the only major change in sediment carbonate/silica contents in this time interval. During the late Miocene through earliest Pliocene (4.37 $\mathrm{Ma}$ ), diatoms formed an increased proportion of the sediments in the near-equator sites. A prominent, early late Miocene carbonate dissolution peak can be recognized within the off-equator Sites $(848,852$, 853 and 844,845$)$, but not in the equatorial sites (849-851), where mat deposits continue to represent the only major variations in carbonate/silica. Loss of carbonate following this dissolution maximum at Sites 844 and 845 does not extend westward.

Several significant changes occurred during the Pliocene. No diatom mat deposits are recognized after ca. $4.37 \mathrm{Ma}$. A further period of carbonate dissolution had its peak between 3.88 and $3.18 \mathrm{Ma}$, and immediately after this, foraminifers became a significant sediment component in all sites (other than 844,845 ) and a major sediment component in Sites 848 and 852. Diatom abundances declined more markedly in sites north of the equator (e.g., Site 851). Some of these changes may relate to the closing of the Panama Isthmus (Keigwin, 1982). A Pliocene-Pleistocene period of increased diatom content in sediments and diatom-rich interbeds is best developed in the south, at Site 846 , and decreases in intensity westward and northward. The timing of this suggests a relationship with the onset of Northern Hemisphere glaciation (Shackleton et al., 1984).

Evidence for hemispheric asymmetry is afforded by the main periods and types of diatom-rich deposition, which must relate to surface processes. Diatom mat deposits and mat fragments can be found extensively north of the equator (e.g., in Sites $852,844,845$ ), and also in sites south of the equator ( 848 and 846 ), which suggests a connection with the Equatorial Current systems (Fig. 1; see Kemp et al., this volume). By contrast, the Pliocene-Pleistocene diatom-rich deposition is most intense at Site 846 and fades to the west and north, suggesting a strong link to the Peru Current-South Equatorial Current system.

The complex and varied causes and expressions of carbonate/silica (and, hence, seismic impedance contrast) variation during the early late Miocene (Fig. 8) suggest that great care will be required when using seismic reflectors as agents for correlating oceanographic events.

\section{ACKNOWLEDGMENTS}

I am most grateful to all my fellow Leg 138 sedimentologists for contributing to the data that this contribution attempts to synthesize. Participation in Leg 138 was funded by the Natural Environment Research Council.

\section{REFERENCES}

Berger, W.H., Ekdale, A.A., and Bryant, P.P., 1979. Selective preservation of burrows in deep-sea carbonates. Mar. Geol., 32:205-230.

Berggren, W.A., Kent, D.V., Flynn, J.J., and Van Couvering, J.A., 1985. Cenozoic geochronology. Geol. Soc. Am. Bull., 96:1407-1418.

Brewster, N.A., 1980. Cenozoic biogenic silica sedimentation in the Antarctic Ocean, based on two Deep Sea Drilling Project Sites. Geol. Soc. Am. Bull., 91:337-349.

Ekdale, A.A., Muller, L.N., and Novak, M.T., 1984. Quantitative ichnology of modern pelagic deposits in the abyssal Atlantic. Palaeogeogr., Palaeoclimatol., Palaeoecol., 45:189-223.

Gage, J.D., and Tyler, P.A., 1991. Deep-Sea Biology: Cambridge (Cambridge Univ. Press).

Keigwin, L.D., 1982. Isotopic paleoceanography of the Caribbean and East Pacific: role of Panama uplift in late Neogene time. Science, 217:350-353.

Kemp, A.E.S., and Baldauf, J.G., 1993. Vast Neogene laminated diatom mat deposits from the eastern equatorial Pacific Ocean. Nature, 362:141-144.

Leinen, M., 1979. Biogenic silica accumulation in the central equatorial Pacific and its implications for Cenozoic paleoceanography. Geol. Soc. Am. Bull., 90:801-803.

Lyle, M., Mayer, L., Pisias, N., Hagelberg, T., Dadey, K., Bloomer, S., and the Shipboard Scientific Party of Leg 138, 1992. Downhole logging as a paleoceanographic tool on Ocean Drilling Program Leg 138: interface between high-resolution stratigraphy and regional syntheses. Paleoceanography, 7:691-700.

Mayer, L., Pisias, N., Janecek, T., et al., 1992. Proc. ODP, Init. Repts., 138 (Pts. 1 and 2): College Station, TX (Ocean Drilling Program).

Mayer, L., Theyer, F., Thomas, E., et al., 1985. Init. Repts. DSDP, 85 Washington (U.S. Govt. Printing Office).

Mayer, L.A., Shipley, T.H., Theyer, F., Wilkens, R.H., and Winterer, E.L. 1985. Seismic modeling and paleoceanography at Deep Sea Drilling Project Site 574. In Mayer, L.A., Theyer, F., Thomas, E., et al., Init. Repts. DSDP, 85: Washington, (U.S. Govt. Printing Office), 947-970.

Mix, A.C., Rogh, W., Pisias, N.G., Veirs, S., Hagelberg, T., Hovan, S., Kemp, A., Leinen, M., Levitan, M., and Ravelo, C., 1992. Color reflectance spectroscopy: a tool for rapid characterization of deep-sea sediments. In Mayer, L.A., Pisias, N.G., Janecek, T.R., et al., Proc. ODP, Init. Repts., 138: College Station. TX (Ocean Drilling Program), 67-77.

Shackleton, N.J., Backman, J., Zimmerman, H., Kent, D.V., Hall, M.A., Roberts, D.G., Schnitker, D., Baldauf, J.G., Desprairies, A., Homrighausen, R., Huddlestun, P., Keene, J.B., Kaltenback, A.J., Krumsiek, K.A.O., Morton, A.C., Murray, J.W., and Westberg-Smith, J., 1984. Oxygen isotope calibration of the onset of ice-rafting and history of glaciation in the North Atlantic region. Nature, 307:620-623.

van Andel, T.H., Heath, G.R., and Moore, T.C., Jr., 1975. Cenozoic history and paleoceanography of the central equatorial Pacific Ocean: a regional synthesis of Deep Sea Drilling Project data. Mem.-Geol. Soc. Am., 143.

\footnotetext{
Abbreviations for names of organizations and publications in ODP reference lists follow the style given in Chemical Abstracts Service Source Index (published by American Chemical Society).
}

Date of initial receipt: 7 June 1993

Date of acceptance: 31 March 1994

Ms 138SR-133 


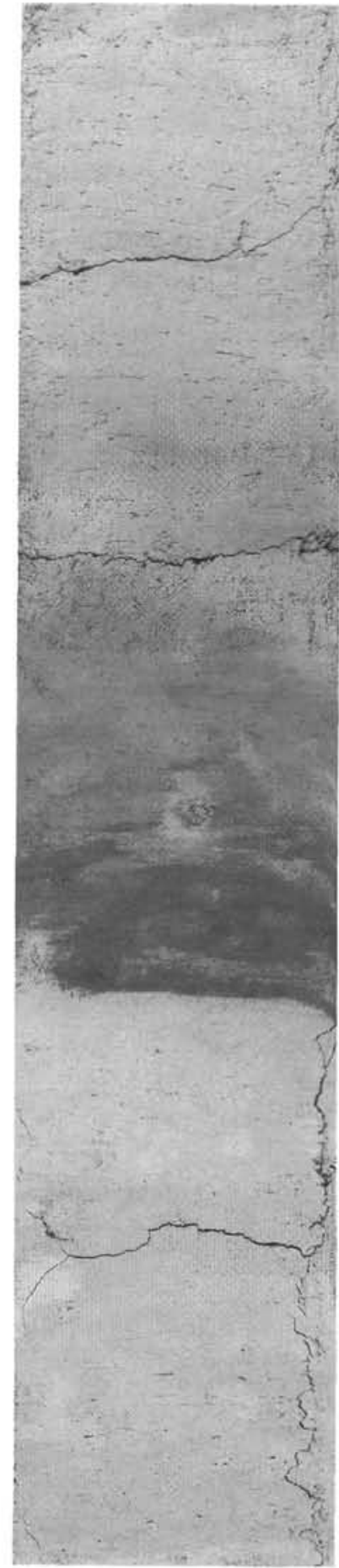

1

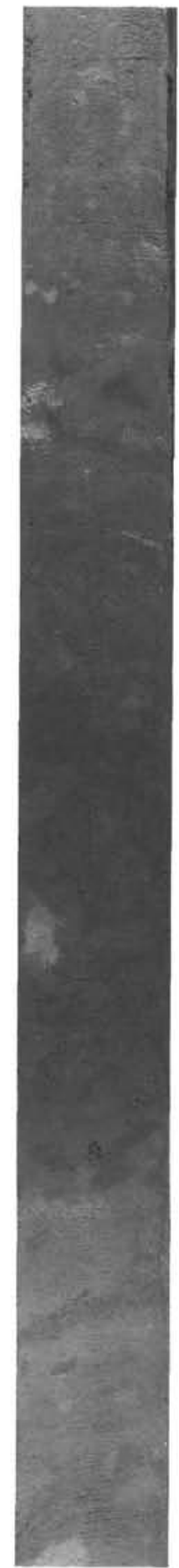

2

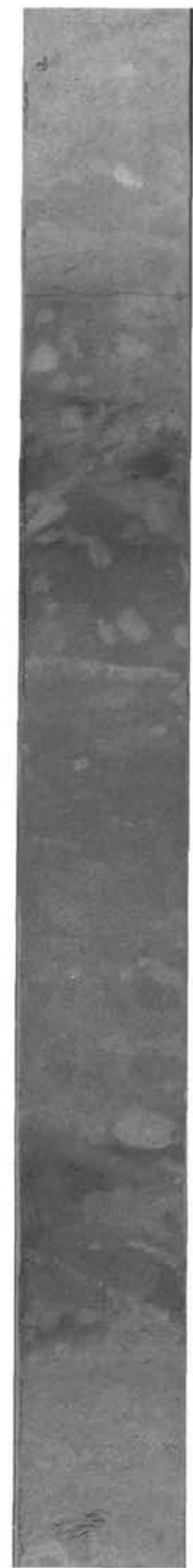

3
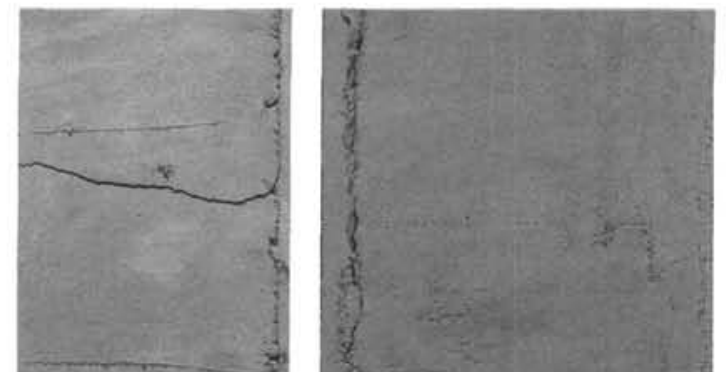
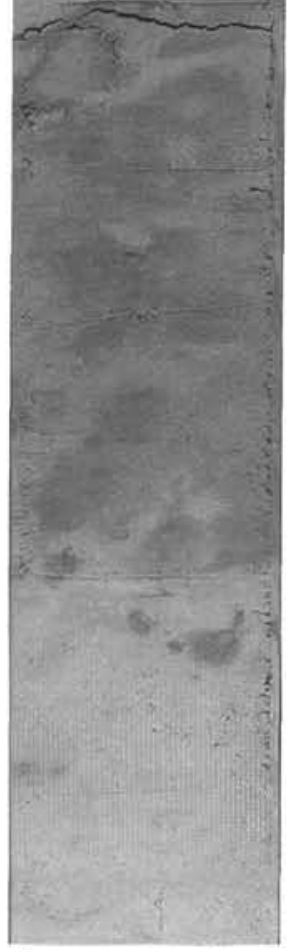

4

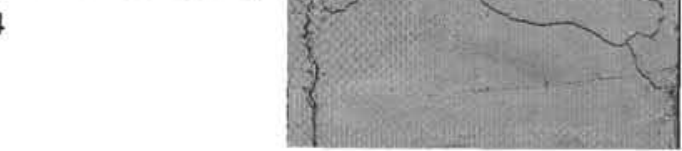

5

Plate 1. 1. An oxide-rich interbed within foraminifer nannofossil ooze from the late Pliocene through Pleistocene section at Site 852 (sedimentation rates: $\sim 12 \mathrm{~m} / \mathrm{m} . \mathrm{y}$.). There is no detectable increase in the relative abundance of siliceous microfossils within this bed $(\sim 1 \%$ radiolarians and no diatoms in both pale and dark lithologies). The only significant difference identifiable from smear slide analysis appears to be the presence of $\sim 8 \%$ oxides within the darker bed (Interval 138-852B-4H-1, 60-90 cm). 2-5. Carbonate-silica cyclicity. Pale/dark color alternations in which the darker beds are characterized by an increase in the relative abundances of radiolarians and commonly also clay, with a reduction and sometimes absence of carbonate (in darker beds). This facies is characteristic of intervals with low to intermediate sedimentation rates. (2) A dark bed of nannofossil radiolarian clay within pale nannofossil ooze (above and below). This bed is near the top of a transitional sequence with bulk sedimentation rates of about $12 \mathrm{~m} / \mathrm{m}$.y., showing progressively upward-increasing carbonate dissolution that culminates in the total loss of carbonate (see text for discussion; Interval 138-845B-15H-1, 17-87 cm). (3) Two darker interbeds of diatom radiolarian clay with oxides interbedded with diatom radiolarian nannofossil ooze in an interval exhibiting considerable carbonate dissolution, with bulk sedimentation rates of $\sim 10 \mathrm{~m} / \mathrm{m} . \mathrm{y}$ (Interval $138-844 \mathrm{C}-6 \mathrm{H}-3$, $77-138 \mathrm{~cm}$ ). (4) A darker bed of clayey diatom radiolarian ooze (smear slide: diatoms: 30\%; radiolarians: $30 \%$; clay: $27 \%$; nannofossils: 10\%; foraminifers: $13 \%$ ) within paler foraminifer nannofossil ooze in an interval with bulk sedimentation rates of $\sim 7 \mathrm{~m} / \mathrm{m}$.y (Interval 138-848D-4H-3, $100-143 \mathrm{~cm}$ ). (5) A darker interbed of radiolarian nannofossil ooze within nannofossil ooze in a sequence with bulk sedimentation rates between 18 and $24 \mathrm{~m} / \mathrm{m} . \mathrm{y}$. (Interval 138-845B-17H-5, 87-117 cm). Scale: all figures show entire core diameter of $6 \mathrm{~cm}$. 


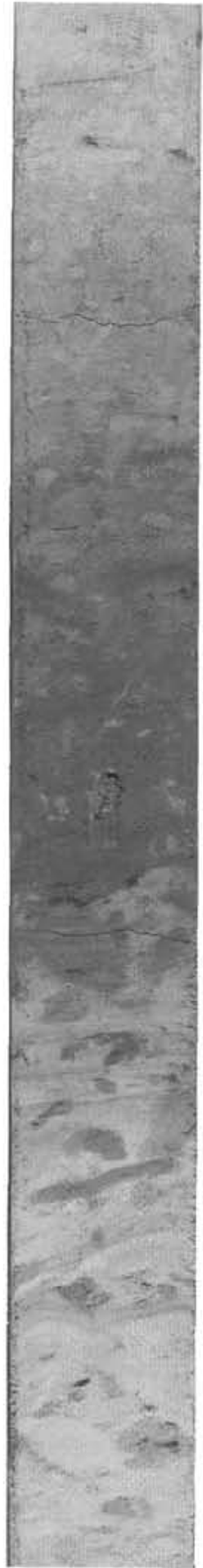

1

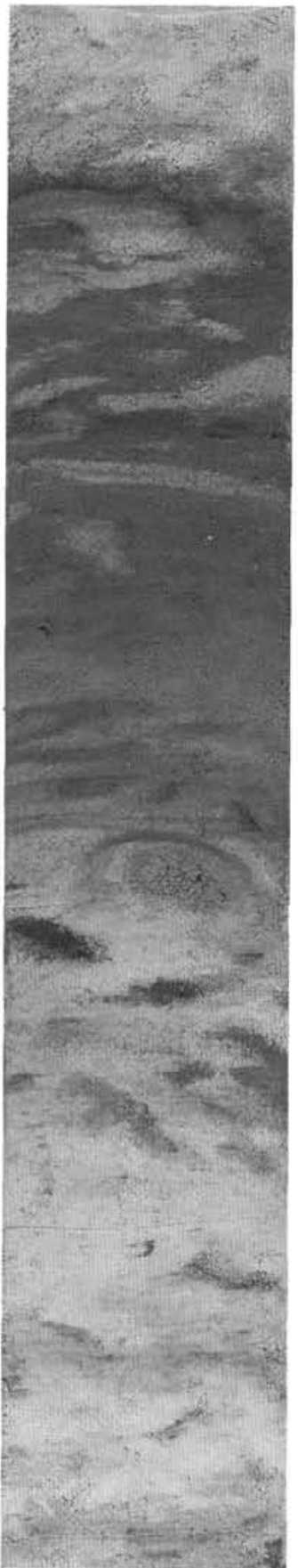

2

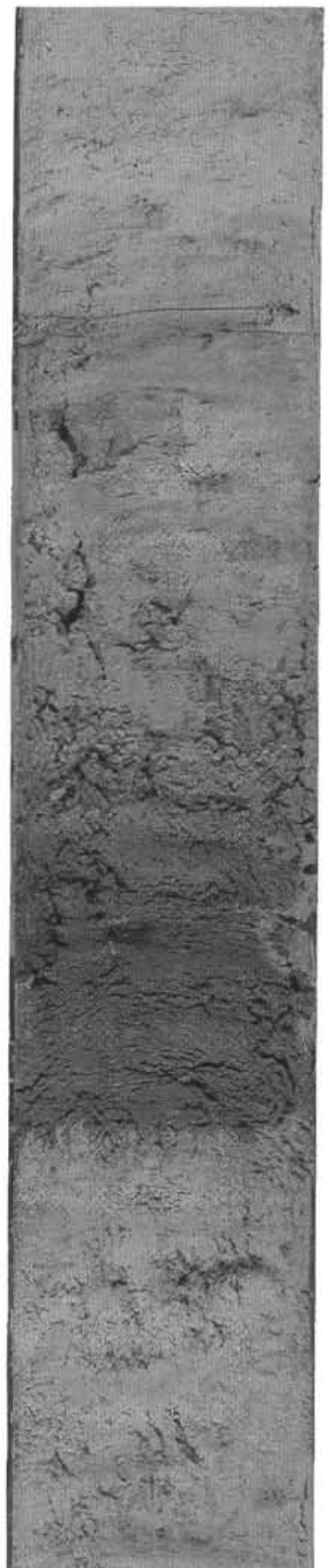

3

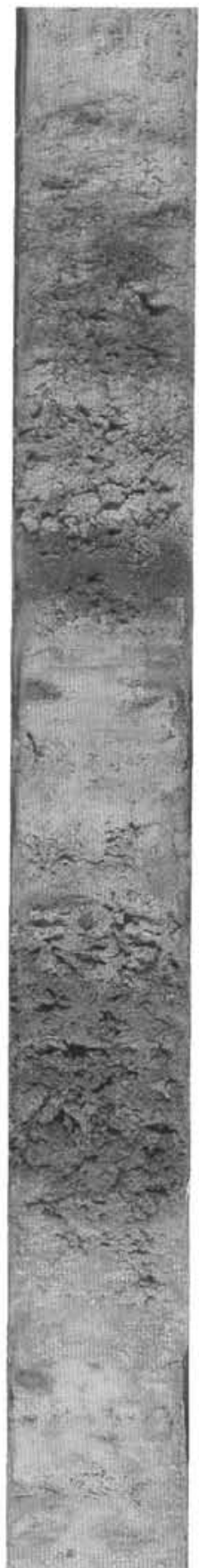

4

Plate 2. 1-4. Carbonate-silica cyclicity (ctd). Pale/dark color alternations in which the darker beds are characterized by an increase in the relative abundance of diatoms and greatly reduced carbonate (although a small number of well preserved calcareous microfossils is generally present throughout such beds). (1) A dark bed of radiolarian clayey diatom ooze within pale radiolarian diatom nannofossil ooze (above and below) in an interval with sedimentation rates of $\sim 27 \mathrm{~m} / \mathrm{m}$.y. (Interval $138-847 \mathrm{C}-12 \mathrm{H}-3,50-105 \mathrm{~cm}$ ). (2) A darker interbed of foraminifer diatom ooze interbedded with foraminifer nannofossil ooze with diatoms in an interval with bulk sedimentation rates of ca. $30 \mathrm{~m} / \mathrm{m} . \mathrm{y}$. (Interval 138-849B-6H-3, 0-35 cm). (3) A darker bed of laminated diatom ooze within paler diatom nannofossil ooze in an interval with bulk sedimentation rates of ca. $122 \mathrm{~m} / \mathrm{m}$.y. (the laminae are not discernible on rough, wire-cut surfaces: see Pl. 3, Fig. 1; Interval 138-850B-20X-7, 6-40 cm). (4) Two interbeds of roughened, wire cut laminated diatom ooze within paler sequence with bulk sedimentation rates between $108 \mathrm{~m} / \mathrm{m}$.y. (Interval 138-849D-19X-2, 23-83 cm). Scale: all figures show entire core diameter of $6 \mathrm{~cm}$. 


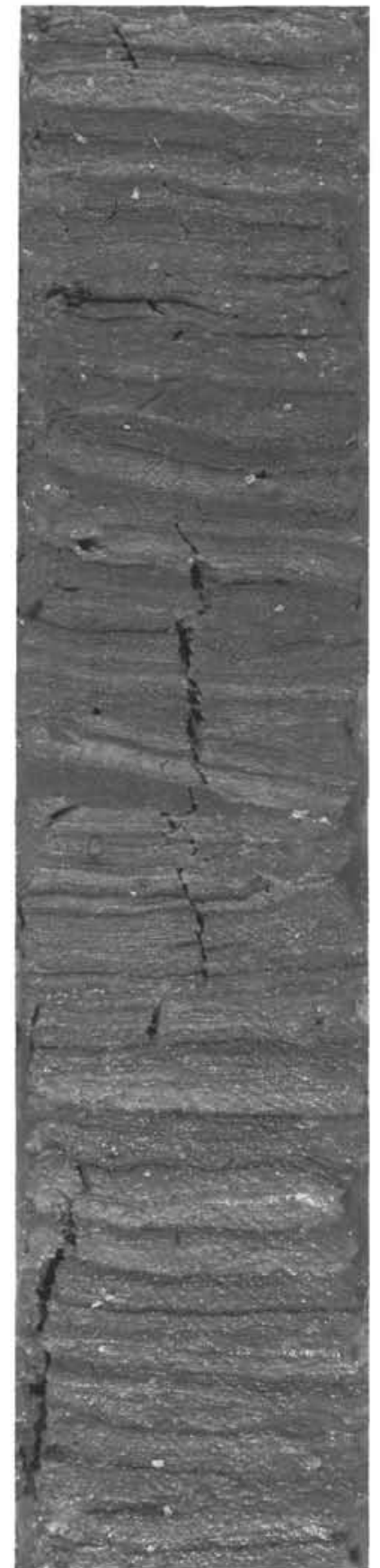

1
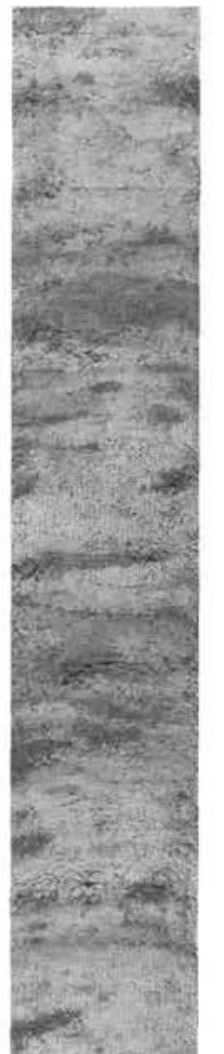

3
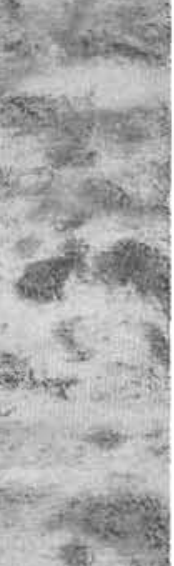
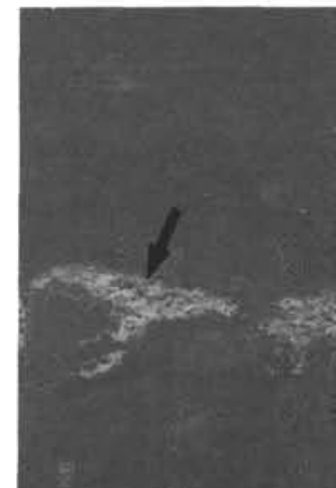

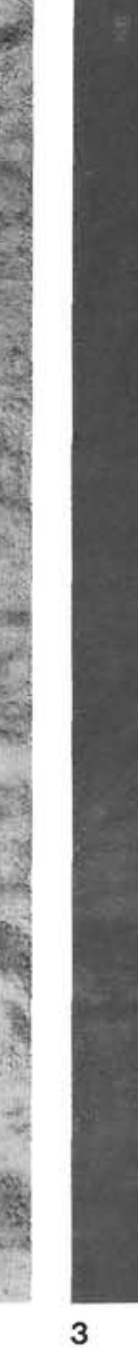

3

Plate 3. 1-3. Laminated diatom mat deposits and bioturbated remnants of laminated diatom mat deposits. (1) Laminated diatom mat deposits clearly visible on a rare saw-cut core surface (Interval 138-851B-29X-5, 85-110 cm). (2) Darker burrow fills of diatom ooze with mat fragments within paler nannofossil-rich sediment in an interval adjacent to laminated diatom ooze (Interval 138-850B-10H-2, 65-125 cm). (3) Exotic, isolated pale burrow fills containing near-monospecific $T$. longissima (arrow) within dark diatom radiolarian clay (Interval 138$845 \mathrm{~B}-14 \mathrm{H}-7,20-57 \mathrm{~cm})$. Scale: all figures show entire core diameter of $6 \mathrm{~cm}$. 


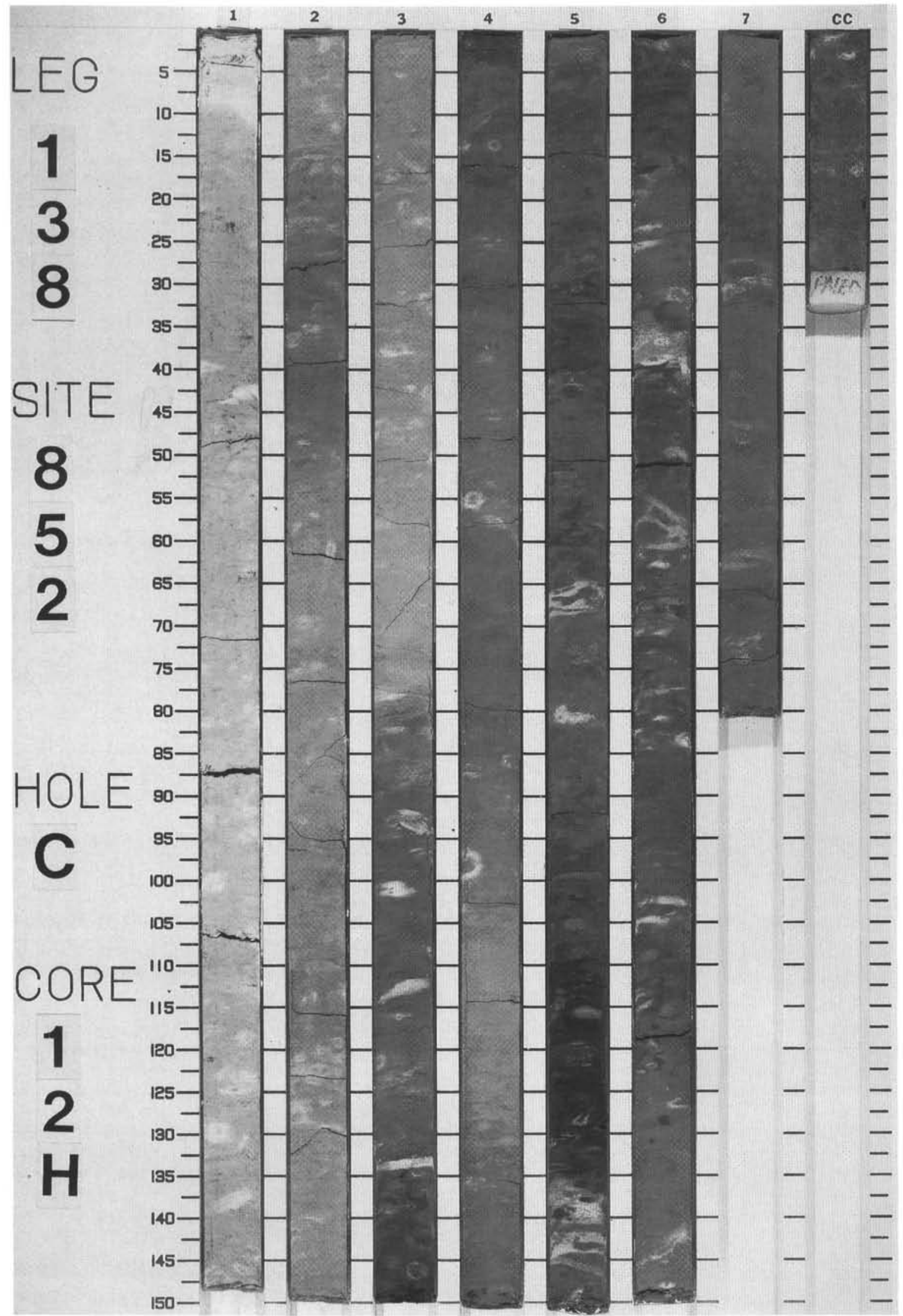

Plate 4. The early late Miocene sequence at Site 852 (Core 138-852C-12H). This shows an interval of oxide-rich beds passing up into a paler sequence of radiolarian nannofossil ooze with foraminifers, containing slightly darker radiolarian-rich interbeds. 